\title{
THE FEDERAL POWER TO REGULATE CHILD LABOR IN THE LIGHT OF SUPREME COURT DECISIONS.
}

The National Child Labor Bills introduced in Congress are based on the proposition that Congress has the right to exclude from interstate commerce the products of a manufacturing or other establishment where conditions destructive of the health or morals of the employees are allowed to exist. The soundness of this proposition can hardly be seriously questioned in the light of the decisions of the Supreme Court of the United States.

There are two views of the power of Congress over interstate and foreign commerce. One was enunciated by Mr. Chief Justice Marshall in Gibbons v. Ogden. ${ }^{1}$ In his opinion the power of Congress over interstate commerce is just as absolute as the power of the States over intra-state commerce, although it cannot, any more than any other power of Congress, be so exercised as to violate any of the constitutional restrictions on the federal power.

"The power over commerce, like all others vested in Congress, is complete in itself, may be exercised to its utmost extent; and acknowledges no limitations, other than are prescribed in the Constitution. *** These limitations are expressed in plain terms. * * * If, as has always been understood, the sovereignty of Congress, though limited to specific objects, is plenary as to those objects, the power over commerce with foreign nations and among the several States, is vested in Congress as absolutely as it would be in a single government, having in its constitution the same restrictions on the exercise of the power as are found in the Constitution of the United States."

The theory thus clearly stated by the great Chief Justice can be illustrated in this way. Suppose Congress passes a bill prohibiting intertate commerce in a certain article. Such an act would be a regulation of commerce. The plenary power of a sovereign to regulate includes the right of absolute prohibition.

${ }^{1} 9$ Wheaton, I, 196-197 (I824). 
The question of the constitutionality of such an act, therefore, depends on the answer, not to the question, Is it a regulation of commerce? but to the question, Does the act violate a constitutional limitation?

There are only two limitations which may restrict the exercise of the power of Congress to exclude an article from interstate commerce. The Fifth Amendment provides that

"No person shall *** be deprived of life, liberty, or property without due process of law."

It can at least be argued,-with what force it is not necessary here to decide, - that an act of Congress which prohibited traffic in an article without express or apparent reason, would deprive owners of their property "without due process." It may also be argued that the Ninth Amendment, by providing that

"The enumeration in the Constitution of certain rights shall not be construed to deny or disparage others retained by the people,"

prohibits a purely arbitrary exercise of power by Congress; and that the exclusion without apparent reason of an article from interstate commerce, would be an arbitrary exercise of power.

It should here be pointed out that under Mr. Chief Justice Marshall's view, the Tenth Amendment imposes no restriction on the power of Congress over interstate and foreign commerce. It provides that:

"The powers not delegated to Congress *** are reserved to the States."

But the power over interstate commerce and foreign commerce is expressly delegated to Congress.

The other view of the power of Congress over commerce is, that besides the express limitations contained in the Constitution, Congress is prevented from so exercising the power as indirectly to regulate matters which it cannot regulate directly. It is said that to allow such regulation would defeat the very purpose of the Tenth Amendment, which reserved to the States the powers not granted to Congress nor prohibited to the States. 
Whatever may be said for or against these two views, the view of Mr. Chief Justice Marshall is today the view of the Supreme Court. In 1895 Congress passed an act for the suppression of the lottery traffic through national and interstate commerce. This act, among other things, makes it an offense to carry a lottery ticket from one State to another. Its constitutionality was attacked and the two views of Congressional power just indicated were presented to the Court. ${ }^{2}$ The majority, taking the position of $\mathrm{Mr}$. Chief Justice Marshall in Gibbons v. Ogden, ${ }^{3}$ decided that the act was constitutional. The minority, adopting the second view, thought the act should be declared void. Since then the constitutionality of the Federal Pure Food and Drugs Act and of the White Slave Act have come before the Court. These decisions also depended upon which of these conflicting views the Court would adopt. The Lottery Case was decided by a divided court, but in the later decisions, Hipolite Egg Co. v. 'United States, ${ }^{4}$ supporting the Pure Food and Drugs Act, and Hoke v. United States, ${ }^{5}$ supporting the White Slave Act, Mr. Chief Justice Marshall's view was followed with the concurrence of every member of the Court.

At the present time, therefore, the members of our highest Court apparently believe that in determining whether Congress has the right to prohibit the interstate transportation of a class of persons or products, only the express limitations of the Constitution need be considered. For this reason it seems unnecessary to bring special arguments to the support of this theory. One argument, however, deserves special mention. A State has the undoubted right to prohibit the manufacture of adulterated food or drugs within its domain; it can also forbid their importation from other States. ${ }^{b}$ A State has the right to forbid the sale of lottery tickets, both parties to the sale being within its borders; it could probably prevent their importation under the reasoning in the Plumley Case. A State has the right to pre-

${ }^{2}$ The Lottery Case, 188 U. S. 32 I (1903).

${ }^{3}$ Supra, n. I.

422 U. S. 45 (I9II).

322 U. S. 308 (1912).

- Plumley v. Massachusetts, 155 U. S. 46 I (I894). 
vent the physical and moral degeneration of children by overwork in manufacturing establishments; but it cannot forbid the article manufactured by child-exploitation from being introduced into the State so long as the article itself is unadulterated and safe. $^{7}$ In other words, while the States can protect their manufacturers from the competition of the makers of adulterated foods, they are powerless to exclude the competition of foreign makers who cheapen their product by the exploitation of child labor. Should Congress lend its aid to the States which protect their child resources, it would therefore be helping them in a field in which they cannot help themselves; whereas in the Food and Drugs Act, Congress enacted federal legislation, not because it was the only protection open to the States, but because it was doubtless the best protection possible.

It would indeed be a serious indictment against the wisdom of the framers of our Constitution to say that they took away from the States the right to protect their own manufacturers from unfair trade practices carried on by competitors in other States, and yet failed to give Congress the power thus taken from the States. For it is unfair competition for a manufacturer to exploit child labor to lessen the cost of production when his com. petitor in another State is either forbidden by law or unwilling to stoop to such practices. Fortunately the framers of the Constitution did not so limit the power of Congress. They have conferred on Congress all the power over interstate and foreign commerce taken from the States. What better exercise of the right of regulation thus conferred could there be than the protection of those engaged in industry from unfair competition?

It has been argued that a law prohibiting the products of exploited, or what we may also call anti-social child labor, from interstate commerce, interferes with the rights of the States, in that it indirectly compels employers of labor to conform to the minimum standards of the Congressional Act or go out of business. Admit that this proposed Act would compel practically all employers of labor to conform to its standards. Is it not better to do this than to have those States which wish to pass laws to

${ }^{7}$ I Leisy v. Hardin, I35 U. S. 100 (1889) ; Schollenberger v. Pennsylvania, I7I U. S. I (18g8). 
protect their children practically forced to do so at the expense of subjecting their manufacturers to the unfair competition of the manufacturers in those States which permit the industrial exploitation of their children?

As stated, however, the argument is a work of supererogation, the question of the power of Congress has already been practically determined by the decisions of the Supreme Court. It has, indeed, been argued that there is a difference between an act which excludes the product of exploited child labor from interstate commerce, and one that excludes lottery tickets, poisonous drugs, or adulterated foods; that these last are not legitimate articles of commerce, while the products of exploited child labor are nevertheless legitimate articles of commerce. To those who make this argument the following quotation from the opinion of the Supreme Court in Hoke v. United States, ${ }^{8}$ is significant. The Court, speaking of the power to regulate commerce, said:

"The power is direct; there is no word of limitation in it, and its broad and universal scope has been so often declared as to make repetition unnecessary. And besides, it has so much illustration by cases that it would seem as if there could be no instance of its exercise that does not find an admitted example in some one of them. Experience, however, is the other way, and in almost every instance of the exercise of the power differences are asserted from previous exercises of it and make a ground of attack."

And so in this case. The differences indicated will be pointed out and magnified. But if it is a reasonable exercise of the power to protect the morals or health of the citizens of a State by excluding from interstate commerce lottery tickets, or poisonous drugs we may be sure that the Supreme Court will also hold that it is a reasonable exercise of the power to protect the manufacturers of a State from unfair trade competition, by excluding from interstate commerce the products of those who would undersell by the exploitation of child labor.

University of Pennsylvania.

William Draper Lewis.

${ }^{8} 227$ U. S., page 320 (1912). 